IRA-International Journal of Management \&

Social Sciences

ISSN 2455-2267; Vol.09, Issue 02 (November 2017)

Pg. no. 55-66

Institute of Research Advances

http://research-advances.org/index.php/RAJMSS

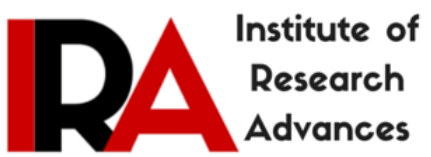

\title{
Per Capita Availability of Food Grains and Pressurized Agriculture Economy in the Reform Period in India
}

\author{
Dr. Sandipan R. Gavhale
}

Annasaheb Waghire College, Otur, Tal-Junnar, Dist-Pune 412409.

Affiliated to Savitribai Phule Pune University, Pune. Maharashtra (INDIA)

Type of Review: Peer Reviewed.

DOI: http://dx.doi.org/10.21013/jmss.v9.v2.p2

\section{How to cite this paper:}

Gavhale, S.R. (2017). Per Capita Availability of Food Grains and Pressurized Agriculture Economy in the Reform Period in India. IRA-International Journal of Management \& Social Sciences (ISSN 2455-2267), 9(2), 55-66. doi:http://dx.doi.org/10.21013/jmss.v9.n2.p2

(C) Institute of Research Advances.

\section{(cc) BY-NC}

This work is licensed under a Creative Commons Attribution-Non Commercial 4.0 International License subject to proper citation to the publication source of the work.

Disclaimer: The scholarly papers as reviewed and published by the Institute of Research Advances (IRA) are the views and opinions of their respective authors and are not the views or opinions of the IRA. The IRA disclaims of any harm or loss caused due to the published content to any party.

Institute of Research Advances is an institutional publisher member of Publishers Inter Linking Association Inc. (PILA-CrossRef), USA. The institute is an institutional signatory to the Budapest Open Access Initiative, Hungary advocating the open access of scientific and scholarly knowledge. The Institute is a registered content provider under Open Access Initiative Protocol for Metadata Harvesting (OAI-PMH).

The journal is indexed \& included in WorldCat Discovery Service (USA), CrossRef Metadata Search (USA), WorldCat (USA), OCLC (USA), Open J-Gate (India), EZB (Germany) Scilit (Switzerland), Airiti (China), Bielefeld Academic Search Engine (BASE) of Bielefeld University, Germany, PKP Index of Simon Fraser University, Canada. 


\begin{abstract}
The purpose of this study was to analyze per capita availability of foodgrains and agriculture system of India. The agriculture is the backbone of our country, but recently the growth of Indian economy the share of agriculture in GDP has declined over the years and even today's productivity of some agricultural products are declining in high extent, if compared with like the USA and China and other countries, as well,the present paper is a new attempt to focus on the dichotomy of excess foodgrain production and large-scale subsidized food distribution on the one hand, and huge wastage and millions of hungry families on the other. As well as, it clearly focuses on the issues that Indian government has not given adequate attention to the storage and transportation of foodgrains during the last three decades or so. At this point, the government is caught between huge foodgrain stocks and the states inability to absorb them. India's agricultural sector is surprisingly fragmented when compared with other countries.
\end{abstract}

Key Words-Per capita food grain availability, Agricultural decadal production ratio, Changes in land use pattern, and Operational land holding size.

\title{
Introduction
}

Generally, we have to consider about challenges and problems concerning Indian agricultural development and the competition with eminent foodgrains of foreign developed countries under the label of new economic reforms, so there is a need to study some important factors e.g. availability of per capita agricultural land holding proportion, irrigation facilities, productivity, advanced instruments, and technology etc. Agriculture is the main business of 60 to $70 \%$ peoples as well as it is the life management also. There farmers' class has been exploited by the natural or artificial calamities e.g. traditional farming, the low productivity of production, small land holding area, alienation of lands, etc. due to all these reasons, their productivity is decreasing, day by day comparatively increasing India's population.

Concisely in 1990, the Congress government (P.V. Narsinharao) acknowledged the affiliation of the WTO. Other than, they strictly followed to undeveloped farming and industries to participate in the world trade competition. Subsequently, the India signed the agreement (GATT-WTO).According to this, India agreed to change the customs route, e.g. under the AOA all non-custom barriers were to be transformed into the custom rate, secondly, India acknowledged to alteration in custom rates in which, (Galati et al 1999) almost 3373 goods cluster existed. Of which goods proportion is near about $65 \%$ in customs range by the name of the country, as well as, they built into the range of 673 to agriculture sub-group custom. An overall consideration, the globalization had been accepted under the pressure by the Indian government.

\section{Objective \\ 1. To study of foodgrain productivity in Indian agriculture. \\ 2. To the study of per-capita foodgrain availability in India. \\ 3. To suggest the remedies after study.}

\section{Hypothesis}

The per capita availability of foodgrains is decreasing due to increasing the proportion of small landholder and decentralization of land.

\section{Research Methodology}

The research methodology is based on the relevant secondary data.

Coverage: The study, confines to a concept of per capita foodgrain availability and marginalization of agricultural land or changing in the foodgrain crop pattern of Indian agriculture.

\section{Literature Review}

There has been reviewed of some articles regarding with the present subject, of which, some research is to be recorded, which is based on some availabilities, and qualities, that is:

1. According to M.S. Swami Nathan \& R.V. Bhavani in Food production \& availability - Essential prerequisites for sustainable food security" (2011), that optimality of food production and essential 
prerequisites are main elements of sustainable food security. In which food and nutrition security are mainly interrelated with a food-based approach, it can help in overcoming malnutrition in an economically and socially sustainable manner, and food production provides the base for food security as it is a key factor in food availability. As well as, the dissimilar aspects of making sure high productivity and production without associated ecological harm by mainstreaming ecological considerations in technology development and dissemination.

2. Das Sandip, in the article of "Agricultural production and food distribution to vulnerable families in India today" clarifies the dichotomy of excess foodgrain production and large-scale subsidized food distribution on the one hand, and huge wastage and millions of hungry families on the other. Further, it clearly focuses on the issues discussed that Indian government has not given adequate attention to the storage and transportation of foodgrains during the last three decades or so. At this point, the government is caught between huge foodgrain stocks and the states inability to absorb them.

3. According to Ahmad Firdos M.D, Haseen Shaukat in "The Performance of India's Food Grains Production: A Pre and Post Reform Assessment" (2012). This article made a modest attempt to analyze the result by considering the change in the growth rate of fertilizer consumption, change in the cultivated area, change in irrigated area and change in climate conditions between two periods, first from 1970- 71 to 1990-91 and second from 1991-92 to 2008-09. For instance, in the case of rice and wheat production is concerned, the picture is quite different in pre and post-reform period. In the pre-reform period, the average percentage change in yield of rice and wheat is 3.36 and 3.06 percent per annum respectively, while in the post-reform period which declined to 1.64 and 1.46 percent per annum respectively.

4. Ramesh Chand and Shinoj Parappurath, "Historical and spatial trends in agriculture: Growth analysis at national and state level in India". This article indicates that an agriculture is the backbone of our country, but recently the growth of Indian economy the share of agriculture in GDP has declined over the years and even today's productivity of some agricultural products is declining, if compared with like the USA and China. As well as, the agriculture sector faces the more problems concerns with decreasing size of operational holdings increasing pressure on agricultural land, diversification \& commercialization of agriculture, shift towards highvalue agriculture.

5. As said by L Krishna Veni \& G Alivelu, in "Production and per capita availability of food grains in India: Analysis" (2005), It shows that net availability of cereals is not adequate to meet the growing needs of the growing population. Hence, the importation of food has become inevitable in India. For instance, the scarcity in the production of pulses e.g. the per capita availability of pulses per day has been lower than the average daily requirement of 67.95 grams per head during the study period.

6.As said by Amarnath Tripathi \& A.R. Prasad, (2009) in "Agricultural Development in India since Independence: A Study on Progress, Performance, and Determinants."This paper covered the period from 1950-51 to 2005-06.which indicates that there is scope to increase both net sown area and gross sown area. It shows that only 39 percent of the net sown area is irrigated the area. After evaluating the changes in agrarian structure, input use pattern and growth trend of agriculture, this study that production and yield instability declined for almost crop during the post-reform period while, area instability increased in the same period, which is the major responsible factor for production instability.

If there are exist some facts in aforementioned studies, there is a need to become a study that what is changed in foodgrain production nature and how effective has been made by per capita food grain net availability.

\section{Facts of Agriculture in Various Constituent}

If the government has executed the $11^{\text {th }}$ five-year plan, we have achieved the agricultural target. Day today, populations strain on the agriculture is increasing and its impact becoming on the Agricultural development. Onward, the percentage of agriculture to total GDP and the expenditure on the irrigation has been mentioned as below. 
Table 1: Agricultural Expenditure and Growth rate on the Five year Plan

\begin{tabular}{|l|l|r|r|r|}
\hline $\begin{array}{c}\text { Sr. } \\
\text { No. }\end{array}$ & $\begin{array}{c}\text { Five year plan } \\
\text { Period }\end{array}$ & $\begin{array}{c}\text { Total plan } \\
\text { expenditure } \\
\text { (actual) }\end{array}$ & $\begin{array}{c}\text { Agriculture } \\
\text { \& allied } \\
\text { sectors }\end{array}$ & $\begin{array}{c}\text { \% of agriculture \& } \\
\text { allied sectors to total } \\
\text { outlay }\end{array}$ \\
\hline 1 & $1951-56$ & 1,960 & 600 & 31 \\
\hline 2 & $1956-61$ & 4,670 & 950 & 20 \\
\hline 3 & $1961-66$ & 8,580 & 1,750 & 21 \\
\hline 4 & $1969-74$ & 15,800 & 3,670 & 22 \\
\hline 5 & $1974-79$ & 39,430 & 8,740 & 24 \\
\hline 6 & $1980-85$ & $1,09,300$ & 26,100 & 21 \\
\hline 7 & $1985-90$ & $2,18,730$ & 47,100 & 20.5 \\
\hline 8 & $1992-97$ & $4,75,480$ & $1,01,590$ & 20.0 \\
\hline 9 & $1997-02$ & $8,59,200$ & $1,76,217$ & 18.5 \\
\hline 10 & $2002-07$ & $15,25,639$ & $3,05,055$ & \\
\hline 11 & $2007-2012$ & $36,44,718$ & $6,74,105$ & 2 \\
\hline
\end{tabular}

Source: 1.Planning Commission (GOT) \& Economic Survey 2000-01.

2. Indian Economy: Dutt \& Sundharam 2012.

Note: Annual Plan-1966-69, 1997-80, 1990-91, 1991-92

Table 1 represents an agricultural expenditure and its share to total outlays on the five-year plan, at the beginning, the first five-year plan (1951-56) Agriculture \& allied sector expenditure was 600 crore (31\%) out of that the total plan expenditure. Hereafter it has been increasing steadily, for instance by orderly, 950 crore $(20 \%)$ outlays for second five-year plan, as well, 1,750 crore $(20 \%), 3,670$ crore $(24 \%), 8,740$ crore $(22 \%)$, 26,100 crore $(24 \%), 47,100$ crore $(23 \%), 1,01,590$ crore $(21 \%), 1,76,217$ crore $(20.5 \%), 3,05,055$ crore $(20.0 \%)$, $6,74,105(18.5 \%)$ outlays were to be third to eleventh five-year plan,which shows that totally outlays on the five year plan is increased by rapidly than that of agriculture outlays as well recently, its share decreased by $2.5 \%$ which is lower than that of need outlays.

Table 2: Agricultural decadal production ratio Area (Lakh Hectare)

\begin{tabular}{|c|c|r|r|r|}
\hline $\begin{array}{c}\text { Sr. } \\
\text { No. }\end{array}$ & Year & $\begin{array}{c}\text { Area } \\
\text { (Million Hr.) }\end{array}$ & $\begin{array}{c}\text { Production } \\
\text { (Million tone) }\end{array}$ & $\begin{array}{c}\text { Production } \\
\text { (kg./Hr.) }\end{array}$ \\
\hline 1 & $1950-51$ & 97.32 & 50.82 & 522 \\
\hline 2 & $1960-61$ & 115.58 & 82.02 & 710 \\
\hline 3 & $1970-71$ & 124.32 & 108.42 & 872 \\
\hline 4 & $1980-81$ & 126.67 & 129.59 & 1023 \\
\hline 5 & $1990-91$ & 127.84 & 176.39 & 1380 \\
\hline 6 & $2000-2001$ & 119.78 & 195.92 & 1636 \\
\hline 7 & $2010-11$ & 126.7 & 245 & \\
\hline
\end{tabular}

Source: directorate of economics and Statistics, The ministry of agriculture, fertilizer association of India.

Table No. 2 shows that proportions of per hectare production, the total area under cultivation land, in 1950 to 2001. If there is increasing the extent of production and cultivation land, since 1950-51, in fact, the production ratio is lower than the increased area. Overall, this situation can't be giving the grantee to be provided food grain for the increasing population. As long as, considering the point of import foodgrains, which comparative production cost is lower than Indian foodgrains, so we are assisting to like this situation, it is also an ideal illusion.

Over and above, this table represents the decadal production ratio and per hectare production in India. Where theper hectare production was about $522 \mathrm{~kg}$. In 1950-51, which was near $1636 \mathrm{~kg}$ ? In 2000-2001, it was increased at three-fold compared with before theyear. This growth is at the very lowest level if considering the population growth. In fact, India is dependent on the other countries regarding the foodgrains. So how can be increased the export share of foodgrains and how can be achieved the benefit of world trade organization, it is an illusion, as well as an across an idea, that how can we get the benefit of globalization, it as a true that, there farming's nature is a traditional, they're landholding ratio is lower, farmers sell the product in the village or to the broker in less price etc. At the present, the Panjabi farmers sell the product in village market, its ratio is higher e.g. Wheat $60 \%$, Oils $70 \%$, and Cotton $35 \%$, besides, remains productions will be sold to brokers, its benefit will not get to the farmers because they are illiterate having not a knowledge of marketing system. They 
are being exploited, so, there will be a failure, says that Indian agriculture will become a developed through of globalization.

Table 3: Net availability, procurement and public distribution of food grains During the last 50 years

(Million tons)

\begin{tabular}{|c|r|r|r|r|r|}
\hline Year & $\begin{array}{c}\text { Net production of } \\
\text { food grains }\end{array}$ & $\begin{array}{c}\text { Net } \\
\text { Imports }\end{array}$ & \multicolumn{2}{|c|}{$\begin{array}{c}\text { Net Availability } \\
\text { of Food grains }\end{array}$} & \multicolumn{2}{|c|}{ Public distribution $^{\text {b }}$} \\
\hline $\mathbf{1}$ & $\mathbf{2}$ & $\mathbf{3}$ & $\mathbf{4}$ & $\mathbf{6}$ & of Col. No.4 $^{-1}$ \\
\hline 1951 & 48.1 & 4.8 & 52.4 & 8.0 & 15.26 \\
\hline 1961 & 72.0 & 3.5 & 75.7 & 4.0 & 5.28 \\
\hline 1971 & 94.9 & 2.0 & 94.3 & 7.8 & 8.27 \\
\hline 1981 & 113.4 & 0.7 & 114.3 & 13.0 & 11.37 \\
\hline 1991 & 154.3 & $(-) 0.1$ & 158.6 & 20.8 & 13.11 \\
\hline 2001 & 172.2 & $(-) 2.9$ & 156.9 & 13.2 & 8.41 \\
\hline $2011(\mathrm{P})$ & 214.2 & $(-) 2.9$ & 203.1 & 47.9 & 23.58 \\
\hline
\end{tabular}

Sources: 1. Department of Food and Public Distribution.

2. Directorate of Economics \& Statistics, Department of Agriculture \& Cooperation

${ }^{\mathrm{a}}$ Net availability $=$ Net production + Net Imports - changes in Government stocks.

${ }^{\mathrm{b}}$ Includes quantities released under the Food for Work Programme during the year 1978 to

1990. [N. Negligible. P Provisional]

Notes: 1. Production figures relate to agricultural year: 1951 figures correspond to 1950-51 and so on. Figures for procurement and public distribution relate to calendar years.

2. Net imports from 1981 to 1994 are only on government account and from 1995 onwards the net imports are total imports and export of the country.

Table No. 3 indicates that in 1951, net production of foodgrains remained at 48.1 million tonnes, if, net imports was 4.8 million tonnes, of which 15.26 ( 8 million tonnes) foodgrain was to be the public distribution out of the net availability of foodgrain in India. Hereafter, until 2011, net production of foodgrains has increased up to 214.2 million tonnes, between this period, net import is also decreased up to (-)2.9 million if the public distribution rate has increased upto $23.58 \%$ (47.9 million).

According to the Economic Survey, 2013-14, released by the Ministry of Finance before budget 2014, there was a record production of foodgrains in 2013-14, especially of Pulses and Oilseeds. There has also been an increase in the net as well as per capita availability of foodgrains.

The National Food Security Mission (NFSM) was launched in 2007. The aim was to increase production of foodgrains. The main foodgrains under the scheme were Rice, Wheat, and Pulses. In the $12^{\text {th }}$ Plan, NFSM has been extended to coarse cereals and cash crops. The new targets are the additional production of foodgrains - total of 25 million tonne foodgrains comprising of 10 million tonne Rice, 8 million tonne Wheat, 4 million tonne Pulses and 3 million tonnes coarse cereals by the end of 12 th Plan.

By Sh. Mohanbhai Kundaria(2015) (Minister of State for Agriculture) given information in Lok Sabha, he said consumption of specific items of foodgrains, varies from place to place and within different sections of people depending upon the preferences of the consumers, their cultural values, income levels, etc. In addition, the government also provides subsidized foodgrains under Targeted Public Distribution System (TPDS) which aims at enhancing the food security for the poor. According to the food ministry, the food subsidy is the difference between purchase price from farmers and the price at which it sold to poor families the government roughly needs 62-63MT of food grains to meet the demand of public distribution system (PDS) and other schemes. Thomas said, on this position "This is three times higher than the buffer norm," enforcement source for example 2009-10 to 2012-13 in four years total amount 268102 crore Food Subsidy offered by the government for public distribution system.

Thomas said, the government roughly needs 62-63 Mt. of foodgrains to meet the demand of public distribution system (PDS) and other schemes. "This is three times higher than the buffer norm," 
Table 4: Per capita net availability of food grains in India during the last 50 years Grams per day as on.16.03.2011

\begin{tabular}{|c|c|c|}
\hline Year & $\begin{array}{c}\text { Food Grains } \\
\text { (Grams Per day) }\end{array}$ & $\begin{array}{c}\text { Food Grains } \\
\text { (Grams Per year) }\end{array}$ \\
\hline 1 & 2 & 3 \\
\hline 1951 & 394.9 & 144.1 \\
\hline 1961 & 468.7 & 171.1 \\
\hline 1971 & 468.8 & 171.1 \\
\hline 1981 & 454.8 & 166.0 \\
\hline 1991 & 510.1 & 186.2 \\
\hline 2001 & 416.2 & 151.9 \\
\hline $2010(\mathrm{P})$ & 438.6 & 160.1 \\
\hline
\end{tabular}

Source: Directorate of economics and statistics department of agriculture and cooperation. NOTE: The net availability of food grains is estimated to be gross production (-) seed, feed \& Wastage,(-) export (+) import, (+/-) change in stocks.

Table No. 4 specifies that, in India, per capita net availability of foodgrains in grams per day and per year was near $394.9 \mathrm{gm}$. and $144.1 \mathrm{gm}$. for 1951 , as well as, if we apprehend this figure of the grain was at 468.7 and 171.1 for 1961, 468.8 and 171.1 for $1971,454.8$ and 166.0 for 1981,510.1 and 186.2 for 1991,416.2 and151.9 for 2001 and 438.6 and 160.1 for 2010.In overall, this clarifies that in beginning the per capita foodgrain availability for per day and per year is increasing very slowly from 1951 to 1991 it increased by $115.1 \mathrm{gm}$. to $42.1 \mathrm{gm}$. Within 40 years, which ratio is very low if compared to national needs? As well, next 20 years, it's decreased by 71.6 gram and 26.1 grams, this thing is horrific for the nation because this foodgrain availability is very low for the human being of India.

Net availability of foodgrains for per capita per day. An average availability of foodgrains per capita per day was 429.8 grams in the 1950 s and increased to 475.5 grams during 1990s. Further, it decreased to 446.6 grams in the first decade of the $21^{\text {st }}$ century. Within foodgrains, all food crops reveal similar trend except coarse cereals. The availability of coarse cereals is continuously declining.

Table 5: Growth rate of Population and food grains during the last 50 years

\begin{tabular}{|c|c|c|c|c|c|c|}
\hline \multirow{2}{*}{$\begin{array}{l}\text { Sr. } \\
\text { No. }\end{array}$} & \multirow[t]{2}{*}{ Census } & \multirow{2}{*}{$\begin{array}{c}\text { Population } \\
\text { (In Crore) }\end{array}$} & \multicolumn{2}{|c|}{ Growth Rate \% } & \multirow{2}{*}{$\begin{array}{c}\text { Food Grains } \\
\text { Production } \\
\text { (M.T.) }\end{array}$} & \multirow{2}{*}{$\begin{array}{c}\text { Growth } \\
\text { Rate } \\
\%\end{array}$} \\
\hline & & & Arithmetic & Geometry & & \\
\hline 1 & 1951 & 36.10 & & & 48.1 & \\
\hline 2 & 1961 & 43.92 & 2.16 & 1.98 & 72.0 & 49.68 \\
\hline 3 & 1971 & 54.82 & 2.48 & 2.24 & 94.9 & 31.80 \\
\hline 4 & 1981 & 68.33 & 2.47 & 2.23 & 113.4 & 19.49 \\
\hline 5 & 1991 & 84.63 & 2.38 & 2.16 & 154.3 & 36.06 \\
\hline 6 & 2001 & 102.70 & 2.15 & 1.97 & 172.2 & 11.60 \\
\hline 7 & 2011 & 121.01 & 1.76 & & 245 & 42.27 \\
\hline
\end{tabular}

Source: 1. Department of Food and Public Distribution.

2. Directorate of Economics \& Statistics, Department of Agriculture \& Cooperation

Table No. 5 points out that, as per census 1951, the Indian population was at 36.10 crore, hereafter, it has been increasing continuously, for instance, it was 43.92 crores was in 1961 than it increased in high extent still 121.01 crores in 2011.It's increased by 77.09 crores between these periods if growth rate has decreased still 1.76 $\%$ in 2011 , it decreased by $0.39 \%$ if compared with the census of 1961 . This rate was higher at $2.47 \%$, in 1981 , as well as, the foodgrain production and its growth rate were by orderly 72.0 MT. and 49.68 in 1961, if, in the latest census, food grain production remained at 245 M.T. and growth rate was $42.27 \%$. Besides, if we considered about arithmetic and geometric growth rate of population, it stood at 2.16 and $1.98 \%$ in 1961, if, it recently stood at $1.76 \%$ arithmetically at 2011 .

In overall, it indicates that the population is increasing very rapidly, but foodgrain production has not increased in properly, its rate was very lower at 11.60 in 2001 census. Because of this imbalance situation, the Indian food security is not sufficient to the fulfillment of Indian needs of foodgrain. 
Table 6: India's Position in world Agriculture 2008- 2011

\begin{tabular}{|c|c|c|c|c|c|c|c|c|c|c|c|}
\hline \multicolumn{12}{|c|}{ 1.Area (Million ha) } \\
\hline \multirow{2}{*}{\multicolumn{2}{|c|}{2011}} & \multirow{2}{*}{ India } & \multirow{2}{*}{ World } & \multicolumn{2}{|c|}{ India's } & \multirow{2}{*}{\multicolumn{6}{|c|}{ Next to }} \\
\hline & & & & Share & Rank & & & & & & \\
\hline \multicolumn{2}{|l|}{ Total Area } & 329 & 13442 & 2.45 & Seventh & \multicolumn{6}{|c|}{ Russian federation, Canada, USA, China, Brazil, and Australia } \\
\hline \multicolumn{2}{|l|}{ Land Area } & 297 & 13009 & $2.3 \mathrm{~s}$ & Seventh & \multicolumn{6}{|c|}{ Russian federation, China, USA, Canada, Brazil, Australia. } \\
\hline Arable Lan & & 159 & 1411 & $11.3 \mathrm{~s}$ & Second & \multicolumn{6}{|l|}{ USA } \\
\hline \multicolumn{12}{|c|}{ 2.POPULATION*(million) } \\
\hline \multicolumn{3}{|c|}{2008} & \multicolumn{2}{|c|}{ India's } & & \multicolumn{3}{|c|}{2011} & \multicolumn{2}{|c|}{ India's } & \\
\hline Item & India & World & $\%$ Share & Rank & Next to & Item & India & World & $\%$ Share & Rank & Next to \\
\hline Total & 1181 & 6750 & 17.5 & Seconc & \begin{tabular}{l|l} 
d & China \\
\end{tabular} & Total & 1241 & 6909 & 18.0 & Second & China \\
\hline Agriculture & 583 & 2617 & 22.3 & Seconc & \begin{tabular}{l|l}
$d$ & China \\
\end{tabular} & Agriculture & 661 & 2617 & 25.2 & Second & China \\
\hline \multicolumn{6}{|c|}{ 3. Economically Active Population *(Million) } & \multicolumn{6}{|c|}{ Economically Active Population *(Million) } \\
\hline Total & 472 & 3178 & 14.9 & Seconc & China & Total & 491 & 3282 & 15.0 & Second & China \\
\hline Agriculture & 262 & 1295 & 20.2 & Seconc & id China & Agriculture & 267 & 1310 & 20.4 & Second & China \\
\hline \multicolumn{6}{|c|}{ 4. Crop Production (Million T) } & \multicolumn{6}{|c|}{ Crop Production (Million T) } \\
\hline $\begin{array}{l}\text { (A) Total } \\
\text { Cereals }\end{array}$ & 267 & 2551 & 10.6 & Third & $\begin{array}{l}\text { China, } \\
\text { USA }\end{array}$ & $\begin{array}{l}\text { (A) Total } \\
\text { Cereals }\end{array}$ & 260 & 2458 & 10.6 & Third & $\begin{array}{l}\text { China, } \\
\text { USA }\end{array}$ \\
\hline Rapeseed & 6 & 58 & 10.3 & Third & $\begin{array}{l}\text { Canada, } \\
\text { China }\end{array}$ & Rapeseed & 8.1 & 59.0 & 13.7 & Third & $\begin{array}{l}\text { Canada, } \\
\text { China }\end{array}$ \\
\hline
\end{tabular}

Source: Agricultural Statistics at aglance.2013.Directorate of Economics \&Statics, Ministry of Agriculture.

Govt of India

Website:http://eands.dacnet.nic.in, FAO, regional office for Asia and pacific, Bankok.

Table No. 6 shows that India situated at 329 million hectare land out of 13442 million hectares land of the world, which proportion is $2.4 \%$ with the seventh rank after the Russian Federation, Canada, USA, China, Brazil, and Australia. If it has the same ranking with at $2.3 \%$ holding area near about 297 million hectares. After countries by the orderly Russian Federation, China, USA, Canada, Brazil, and Australia.as well, it has 159 million hectares arable land at $11.3 \%$ with the second rank after the USA.

According to census 2011, the total population of India is near 1241 million, which share is $18 \%$ with second ranking out of the total world population, if, in agriculture engaged population is around 661 million, which was 583 million with a share of $22.3 \%$ in 2008. In brief, it shows that the agricultural population of India is increased by $2.9 \%$ if the general population is increased by $0.5 \%$ between the given periods. As well as, as per late census, the total economically active population is near $15 \%$, which was at $14.9 \%$ in 2008 ; it increased by about $0.1 \%$. If, at the same period, the economically active population in agricultural was $20.4 \%$, which was increased by $0.2 \%$ if compared with the year 2008. In overall, the population is increasing by day after day, but, if compared with them the agriculture proportion has declined, notwithstanding the total cereal production also declined from 7 million tonnes in 2011 if compared with the year of 2008.

There has been studied the agricultural changing pattern during 1951 to 2001, wherein, contains the total geographical area, comprising the cultivable land area, changing in the irrigated land, as well as the cropping pattern also have been considered here.

Table 7: Changes in land use pattern in India from 1950-51 to 2001-02

\begin{tabular}{|l|l|l|l|l|l|l|}
\hline (In Thousand hectares) & $1951-52$ & $1961-62$ & $1971-72$ & $1981-82$ & $1991-92$ & $2001-02$ \\
\hline Category & 328726 & 328726 & 328726 & 328726 & 328726 & 328726 \\
\hline Geographical Area & 287827 & 299151 & 304141 & 304272 & 304900 & 305014 \\
\hline Reporting Area for land use & $(87.56)$ & $(91)$ & $(92.52)$ & $(92.56)$ & $(92.75)$ & $(92.79)$ \\
\hline Area under non-agriculture land & 12690 & 14795 & 16972 & 19686 & 21465 & 24070 \\
& $(4.41)$ & $(4.95)$ & $(5.58)$ & $(6.47)$ & $(7.04)$ & $(7.89)$ \\
\hline Barren and uncultivable land & 37484 & 35921 & 27996 & 20010 & 19270 & 17709 \\
& $(13.02)$ & $(12.01)$ & $(9.20)$ & $(6.58)$ & $(6.32)$ & $(5.81)$ \\
\hline Net sown Area & 119400 & 135399 & 139721 & 141928 & 141632 & 141416 \\
& $(41.48)$ & $(45.26)$ & $(45.94)$ & $(46.64)$ & $(46.45)$ & $(46.36)$ \\
\hline Gross sown area & 131893 & 152772 & 165791 & 172630 & 185742 & 185704 \\
Cropping intensity & 111 & 115 & 118 & 123 & 130 & 131 \\
\hline
\end{tabular}




\begin{tabular}{|l|l|l|l|l|l|l|}
\hline Forest land under good tree cover & 48889 & 54189 & 63771 & 67422 & 67866 & 69511 \\
& $(16.98)$ & $(18.11)$ & $(20.97)$ & $(22.15)$ & $(22.15)$ & $(22.79)$ \\
\hline Misc. tree crops and groves & 7881 & 4500 & 4284 & 3715 & 3761 & 3370 \\
& $(2.73)$ & $(1.50)$ & $(1.41)$ & $(1.22)$ & $(1.23)$ & $(1.10)$ \\
\hline Cultivable Waste lands & 23929 & 18632 & 17456 & 16475 & 14994 & 13405 \\
& $(8.31)$ & $(6.23)$ & $(5.74)$ & $(5.41)$ & $(4.92)$ & $(4.39)$ \\
\hline Current fallows & 13808 & 11155 & 12669 & 13173 & 14672 & 14643 \\
& $(4.80)$ & $(3.73)$ & $(4.16)$ & $(4.33)$ & $(4.81)$ & $(4.80)$ \\
\hline Old Fallows & 15154 & 10478 & 8312 & 9862 & 9941 & 10304 \\
& $(5.26)$ & $(3.50)$ & $(2.73)$ & $(3.24)$ & $(3.26)$ & $(3.38)$ \\
\hline Permanent pastures and grazing & 8592 & 14082 & 12960 & 12007 & 11299 & 10586 \\
lands & $(2.98)$ & $(4.70)$ & $(4.26)$ & $(3.95)$ & $(3.71)$ & $(3.47)$ \\
\hline
\end{tabular}

Source: Agricultural Statistics at a Glance (2008)

Note: figure in parentheses indicates percentage to Reported Area

Table No. 7 shows that about changes in land use pattern in India from 1950-51 to 2001-02during this period the total geographical area was near 328726thousand hectares. Of which, the area of land used was near 287827(87.56\%) thousand hectare. In 1950-51 after this increased near till 305014(92.79) thousand hectares. In 2000-01, similarly, in this year area under non-agricultural land was 12690 (4.41) thousand hectare, Barren and uncultivable land 37484(13.02 \%), net sowed Area 119400(41.48 \%), which covered area increased dissimilarly in 2000-200. For instance, the area under nonagricultural land increased at 24070 (7.89) thousand hectare. Barren and uncultivable land and net sowed Area also increased which proposed at 17709(5.81) thousand hectare, and 141416 (46.36) thousand hectare, respectively. But 2011 estimate, saying that the agricultural land is $60.5 \%$ and in which arable land is $52.8 \%$, permanent crops $4.2 \%$ permanent pasture $3.5 \%$, forest $23.1 \%$, and other $16.4 \%$ in India.

\section{Table 8: The percentage Distribution of operational Holding by Size Class} 1960-61 to 2000-01

\begin{tabular}{|l|r|r|r|r|r|}
\hline \multicolumn{7}{|c|}{ (i) Share in Number of Holding (In percentage) } \\
\hline Category & $1960-61$ & $1970-71$ & $1980-81$ & $19990-91$ & \multicolumn{1}{c|}{$2000-01$} \\
\hline Marginal & 40.69 & 50.6 & 56.4 & 59.4 & 63.0 \\
\hline Small & 22.29 & 19.1 & 18.1 & 18.8 & 18.80 \\
\hline Semi-Medium & 18.8 & 15.2 & 14.0 & 13.1 & 11.7 \\
\hline Medium & 13.4 & 11.3 & 9.1 & 7.1 & 5.4 \\
\hline Large & 4.9 & 3.9 & 2.4 & 1.6 & 1.02 \\
\hline \multicolumn{7}{|c|}{ (ii) } & Share in Operated Area (In percentage) \\
\hline Marginal & 6.6 & 9.0 & 12.0 & 15.1 & 18.82 \\
\hline Small & 12.17 & 11.9 & 14.1 & 17.4 & 20.18 \\
\hline Semi-Medium & 19.93 & 18.4 & 21.2 & 23.2 & 23.96 \\
\hline Medium & 30.51 & 29.8 & 19.6 & 27.0 & 23.84 \\
\hline Large & 30.74 & 30.9 & 23.0 & 17.3 & 13.21 \\
\hline \multicolumn{7}{|c|}{ (iii) } & Average Size (in Hectares) \\
\hline Marginal & -- & 0.41 & 0.39 & 0.039 & 0.40 \\
\hline Small & -- & 1.44 & 1.44 & 1.43 & 1.41 \\
\hline Semi-Medium & -- & 2.81 & 2.78 & 2.76 & 2.72 \\
\hline Medium & -- & 6.08 & 6.02 & 5.9 & 5.80 \\
\hline Large & -- & 18.1 & 17.41 & 17.33 & 17.18 \\
\hline
\end{tabular}

Source: Agricultural Census Division, Ministry of Agriculture, New Delhi.

Note: Marginal - 0 to 1 hectare; Small - 1 to 2 hectare; Semi-medium 2 to 4 hectare, Medium 4 to 10 hectare and Large 10 and above hectare.

Table No. 8 identifies that the percentage distribution of operational holding by size in the social groups during 1960-61 to 2000-01, in 1960-61, the marginal operated area was about 40.69\%, as well with orderly, small, semi-medium, medium, and large operating areas proportion were at $22.29 \%, 18.8 \%, 13.4 \%$, and $4.9 \%$, respectively. Out of which, the marginal land holding proportion has increased to $63.0 \%$,if others land operating holding proportion has been decreased during this period, for instance small, semi-medium, medium 
and large operating land holding proportion were decreased by orderly till $18.80 \%, 11.7 \%, 5.4 \%$ and $1.02 \%$ respectively.

In the second part of the table shows that the percentage of the operated area through of its various categories, for instance, Marginal at $6.6 \%$, Small at $12.17 \%$, Semi-Medium at 19.93, Medium at 30.51 and Large operating area share was at 30.74,out of total operated area in 1960, which proportion were changed till 2000-01, it proposed at differently for instance Marginal ratio increased till 18.82\%, as well, Small and SemiMedium operating area also increased till $20.18 \%$ and $23.96 \%$ similarly Medium and Large operating area share were decreased till $23.84 \%$ and $13.21 \%$, respectively. Finally, it observed that marginal and small land operating size in hectare was very lower at 0.41 ha. And 1.44 hectare as well medium and large average sizes were proposed at 6.08 hectare and 18.1 hectares. Which has not changed in more extent till 2000 to 2001 ? Here one thing has been observed that marginal and small average holding size has been decreased, it means the nonlandholder proportion is increasing constantly which thing is unsafe in view of developing the economy in India.

Table 9: Sources of Irrigation

Area (Million hectare)

\begin{tabular}{|l|r|r|r|r|r|r|}
\hline \multicolumn{1}{|c|}{ Sources } & \multicolumn{2}{|c|}{$1950-51$} & \multicolumn{2}{c|}{$1970-71$} & \multicolumn{2}{c|}{$2000-01$} \\
\hline & \multicolumn{1}{|c|}{ Area } & \multicolumn{1}{c|}{$\%$} & \multicolumn{1}{c|}{ Area } & \multicolumn{1}{c|}{$\%$} & \multicolumn{1}{c|}{ Area } & \multicolumn{1}{c|}{$\%$} \\
\hline Canals & 8.29 & 44.0 & 12.80 & 40.5 & 17.1 & 31.3 \\
\hline Well including Tube wells & 5.98 & 31.7 & 12.10 & 38.3 & 30.9 & 56.6 \\
\hline Tanks & 3.61 & 19.1 & 4.10 & 13.0 & 3.1 & 5.7 \\
\hline Others & 0.97 & 5.2 & 2.60 & 8.2 & 3.5 & 6.4 \\
\hline Total & 18.85 & 100 & 31.60 & 100 & 54.6 & 100 \\
\hline
\end{tabular}

Source: Indian Agriculture in brief, $21^{\mathrm{st}} \mathrm{Edn}, 1986 \mathrm{CMIE}$, Statistical Abstract, India, 2004

Table No. 9 show during 1950-51, the total area under irrigation was accounted for 18.85 (million hectares), of which Canals covered $8.29(44.0 \%)$ million hectare, Well including tube wells covered $5.98(31.7 \%)$ million hectare., Tank covered 3.61 (19.1\%) million hectare area and other sources covered near 0.97 (5.2) million hectare area. If which area under various sources having increased in 2000-2001under the Canals 17.1 (13.3\%) million hectares. Well including tube wells was at 30.9 (56.6\%) million hectare, as well, Tanks and others area increased till $3.1(5.7 \%)$ to $3.5(6.4 \%)$ million hectare out of the total irrigation area (54.6 million hectares),respectively.

Table 10: Changes in irrigated Area in India from 1950-51 to 2000-01

(In Thousand Hectares)

\begin{tabular}{|l|r|r|r|r|r|r|}
\hline Category & \multicolumn{1}{|c|}{$1950-51$} & \multicolumn{1}{|c|}{$1960-61$} & \multicolumn{1}{|c|}{$1970-71$} & $1980-81$ & $1990-91$ & \multicolumn{1}{|c|}{$2000-01$} \\
\hline Net irrigated area & 20853 & 24661 & 31103 & 38720 & 48023 & 54836 \\
\hline Gross irrigated area & 22563 & 27980 & 38195 & 49775 & 63204 & 75821 \\
\hline Irrigation intensity (in \%) & 108 & 113 & 123 & 128 & 132 & 138 \\
\hline
\end{tabular}

Source: Agricultural Statistics at a Glance (2008)

Table No.10 designates that India covered, gross irrigated area near22563 thousand hectares as of 1950-51, of which, the net irrigated area was near 20853 thousand hectares as well, its irrigated intensity was at $108 \%$ in the same period. The hereafter the gross irrigated area was increased till 75821 thousand hectare. As well as the net irrigated area also increased till 54836 thousand hectare. With its intensity remained at $138 \%$ in 2000-01.

If we compared the proportion of total infertile land to under the cultivation land as well as the total area of India, it exists in large extent. Due to as above the different causes around 158 million hectares. The land has laid down as an infertile land. If, under the flooded land extent is increased by 20 million hectares to 40 million hectares. Besides, near about $80 \%$ land is under the dry land area. As well, 30 percent water floats down as a stream, and get into rivers and the ocean, if $40 \%$ water evaporates lack of its proper management remains only $40 \%$ of the cultivation of crops. It means our failure to bringing the proper management of the water system. Due to this irrigation extent has decreased; its effects befell on the decreasing of agricultural produce.

Table 11: Changes in Cropping Pattern of food grain in India since 1950-51

\begin{tabular}{|c|r|r|r|r|r|r|}
\hline Crops & $1950-51$ & $19960-61$ & $1970-71$ & $1980-81$ & $1990-91$ & \multicolumn{1}{|c|}{$2000-01$} \\
\hline Total food grains (\%) & 76.7 & 75.7 & 75.4 & 73.9 & 68.9 & 65.83 \\
\hline
\end{tabular}

Source: Agricultural Statistics at a Glance (2008) 
Table 11 indicates the changes in cropping pattern in India since 1950-51 to 2000-2001, in beginning decades the total food grain production was at a higher level near $76.7 \%$, hereafter, it increased steel 1980-81 remained at $73.9 \%$, after this decade, it decreased constantly, which remained at $68.9 \%$ in $1990-91$, then it decreased to $65.83 \%$ in $2000-2001$.

Amaranth Tripathi, A.R. Prasad's article indicates that the area under non-food crops as a proportion of the total cropped area is increasing but still there is the dominance of food crops. At the beginning of the economic planning in India, 76.7 percent land was put under food crops and about 23.3percent of non-food crops. By 2001, the area under food crops had come down to 65.83 percent and under non-food crops has increased to 34.17 percent. This shift in the allocation of the area from food crops to non-food crops reflects a change from subsistence cropping to commercial cropping. This shifting of land from food crops to non-food crops were mainly influenced by the prevailing price in market and profitability per hectare.

\section{Finding}

- In $9^{\text {th }}$ five-year plan, agricultural growth rate was at $2.06 \%$, and the total expenditure share of GDP is also decreasing as of $6^{\text {th }}$ five-year plan. In brief, there is needed to become a study of the proportion of land under the cultivation, availability of irrigation, and the rain extent, while studying of production cost and growth rate. If consider about the cultivation land in India, especially having a fourth ranking across the world, besides, having a production efficiency to fulfill the need of foodgrain across the nation. But it can't be developed because of political desire, which can be maintained deliberately.

- Since first to eleventh five-year plan in India, an agriculture expenditure ratio has been declined till $31 \%$, which was before planning near $18.5 \%$, however, an actual expenditure in price has been increasing persistence.

- In the beginning of the $20^{\text {th }}$ century, per capita accessibility of foodgrains was nearby $200 \mathrm{~kg}$. per annum, which was around $150 \mathrm{~kg}$ ? (per annum) in half century of British era. and $158 \mathrm{~kg}$.(per annum) was in 2002-2003. It means proportion national averages are near around $155 \mathrm{~kg}$. (per annum) on this review, we can get an idea of what is the situation in poor rural areas.

- Even though we say that, India is one of an agrarian country, but, recently one thing is true that onefifth population face a hunger crisis, to improve this situation, govt. executed a food security rule, with this support, it seems that we cannot provide or give the guarantee to acquire the foodgrain for the growing population through of agriculture development. However, existing this circumstance, our government having not any planning of how can be exported of foodgrains? And which type of and what will become an effect on the foodgrain production?

- When we study of the post-reform Indian economy, especially agricultural development shows that an average growth rate of irrigated area was at $2.02 \%$ in pre-reforms period; as well it was same at $2.02 \%$ in post-reform period. As well as, the average growth of yield of foodgrain production was at $2.6 \%$ in the pre-reforms period, if; it was at $2.65 \%$ in the post-reform period. It means the average yield is increased by $0.05 \%$ in the post-reform period. Moreover, the growth rate of the area under cultivation of total foodgrain production was at $0.2 \%$ in pre-reforms period, which was decreased by $0.41 \%$ in the post-reform period, it means, cultivated land under foodgrain production is decreasing by rapidly. Other than, an average growth rate of foodgrain production was at $2.8 \%$ in the pre-reform period, afterwards, which was declined by $1.98 \%$ in the post-reform period, in India.

- Table 8 indicates having described of land holding proportion, which was remained at $40.59 \%$ in 1951 , hereafter it increased to $63.0 \%$ in 2001.

- In truly speaking, the marginal and small holding land is used for foodgrain production. If medium and large land holding areas are used for commercial land, which farmers obtain of the great benefit of this farming?

- Mostly The marginal land holding farmers belong to SC and ST category, they don't afford to cultivate and developed their land, as well, some farmers have shifted into urban areas for their livelihood, because of this reason the marginal land set an under of infertile land, consequently the foodgrain production have not increased adequately. Besides, the medium and large farmers don't use all holding land for foodgrain production cause of inadequate supply of labours. So lots of land remains as an uncultivable land, sometimes it used for fodders on animals.

\section{Suggestion}

- Recently, the foodgrains need of the total population have not been fulfilled, if, it can be happened by providing the proper facility to marginal farmers who cultivates the foodgrain land through of this way the ideas of communal land come to be the truth because. 
- Generally, we know that some reasons of low productivity, of which, one is decentralization of land and another is the high extent of marginal farmers, as well these constraints as a limitation to government implementation programs in agriculture reforms.

- As per practice, many farmers have been excluded from the benefit of govt. schemes (e.g. Subsidy, Well, Cultivators etc.), because of land holding limitations. So betterment of this situation government should apply communal farming program for marginal farmers, in which 3 to 5neighbor farmers must be coming together and develop cooperative agriculture system, then should be provided with the benefit of the schemes, hereafter, certainly foodgrain productivity will be increased rapidly.

- As well, marginal farmers clubbing schemes should be executed by the government by providing modern farming instruments to this group, as well as the disintegration of the land process should be bounded properly due to this the agriculture productivity will increase by more extent.

- As well, the crop pattern should be changed to be increased the productivity of foodgrain, because recently, many farmers have turned to commercial crop production because of lacking an affordable price of cash crops, so there is a need to provide an affordable price with guaranty by the government.

- The land holding area (shilling Act) definition should be renovated with including some changes, for instance, the operating area should depend on their proportion of family members in place of the individual operating system, then remains land can be distributed among landless farmers, as well, the big farmers who don't cultivate his complete land and keep up any area as wasted land, because a lack of labors.

- An Indian agriculture has a lot of scopes to be increased an irrigated area, for betterment in this situation, reliably a various programme should be executed by the government, for instance, more incidence should be given on the storage water, rainwater management system, as well modern water providing system should be used in irrigated land instead of the traditional system.

\section{Conclusion}

The foodgrain cultivation area should be increased to fulfill that need of growing population as well as an infertile land area should be declined by executing the proper remedies, for instance. For instance, an investment should be increased on irrigation, agricultural instruments, modern seeds and fertilizers, etc. due to this, the foodgrain productivity and purchasing power of poor people also can be increased appropriately.

\section{References:}

[1] https://www.cia.gov/library/publications/the-world-

[2] Amarnath Tripathi, A.R. Prasad Agricultural Development In India Since Independence: A Study On Progress, Performance, And Determinants; Journal of Emerging Knowledge on Emerging Markets, Vol. 1 [2009], Art. 8 Published by DigitalCommons@ Kennesaw State University, 2009

[3] C. L. L. Gowda, P. Parthasarathy Rao and S. Bhagavatula ICRISAT (2009), IndiaGlobal trends in production and trade of major grain legumes.International Conference on Grain Legumes: Quality Improvement, Value Addition and Trade, February 14-16, 2009, Indian Society of Pulses Research and Development, Indian Institute of Pulses Research, Kanpur, India.

[4] C. Parvathi, K. Arulselra (2013) a situational analysis of agricultural production and food security in India.

[5] Debabrata Mukhopadhyay*, Nityananda Sarkar (2014), Convergence of Food grains Production across Indian States: A Study with Panel Data.Discussion Paper ERU/2014.

[6] Department of Agriculture and Cooperation Ministry of Agriculture Government of India March, 2011, Annual Report 2010-2011.

[7] Economics Survey (2011-12), Statistical Appendix.

[8] General survey of agriculture farm sector news releases, agricultural situation in India, may 2015.

[9] GOI, India's position in world Agriculture in 2008.

[10] GOI, Ministry of Agriculture, Department of Agriculture \&cooperation Directorate of Economics and Statistics, New Delhi- (2013)- Pocket Book on Agriculture Statistics.

[11] GOI, Ministry of Agriculture ,Department of Agriculture \& cooperation Directorate of Economics and Statistics, New Delhi- State of Indian Agriculture 2012-13

[12] GOI, Planning Commission of India - Eleventh five year plan (2007-12), Volume iii. Agriculture, Rural Development, Industry, Services, \&Physical Infrastructure.

[13] GOI, Planning Commission of India $-12^{\text {th }}$ five year plan Economics Sectors (2012-17), Volume II.

[14] Indian Agriculture research institute, New Delhi- Agriculture policy: Vision 2020.

[15] L Krishna Veni \& G Alivelu (2005), Production and per capita availability of food grains in India: Analysis, The IUP Journal of Agricultural Economics, IUP Publication, Vol-0(1).

[16] M. S. Swaminathan \& R. V. Bhavani (2013), M. S. Swaminathan Research Foundation (MSSRF), Chennai, India; Food Production \&Availability-Essential Prerequisites for Sustainable Food Security, Pub: Indian J Med Res 138, September 2013, pp 383-391. 
[17] M.D. Firdos, Ahmad, Shaukat Haseen (2012), The Performance of India's Food Grains Production: A Pre and Post Reform Assessment.International Journal of Scientific and Research Publications, Volume 2, Issue 3, March 1 ISSN 2250-3153.

[18] Ministry of Agriculture, Agriculture at a Glance.

[19] Mohd Rais, CSIR -NISTADS, Food Security \& Sustainable Development.

[20] National Statistical Commission Government of India (2012), Report of the Committee on Unorganized Sector Statistics.

[21] Navjit Singh (2011), Indian Agriculture: Before and After Economic Reforms, European Journal of Business and Management www.iiste.org ISSN 2222-1905 (Paper) ISSN 2222-2839 (Online) Vol. 3, No.4.

[22] Pooja Sharma, Ashok Gulati, (2012), ICRIER Policy Series No. 14, March-2012. Approaches to Food Security in Brazil, China, India, Malaysia, Mexico, and Nigeria: Lessons for Developing countries.

[23] Pursuit and promotion of science, Agriculture.

[24] R. Ramakumar, Recent trends in agricultural credit in India: a note.

[25] Ramesh Chand and Shinoj Parappurathu,Historical and Spatial Trends in Agriculture:Growth Analysis at National and State level in India, National Centre for Agricultural Economics and Policy Research, New Delhi.

[26] Samarendu Mohanty, E. Wesley Peterson, Food security IN Developing countries: A case study for India.

[27] Sandip Das,agricultural production and food distribution to vulnerable families in India today.

[28] Sh. Mohanbhai KundariaPress Information Bureau Government of India Ministry of Agriculture 24-February-2015 13:13 IST

[29] Shweta Saini, Marta Kozicka (2014),Evolution and Critique of Buffer Stocking Policy of India.

[30] Upali A. Amarasinghe1, Tushaar Shah1 and O.P. Singh2, Changing consumption patterns: Implications on food and water demand in India.

[31] Venkatesh Athreya,Agrarian Crisis - An Overview.

[32] Vijay Paul Sharma (2012),Accelerating Agricultural Development for Inclusive Growth: Strategic Issues and Policy Options.

[33] WHO Technical Report Series, 916. Diet, Nutrition \& the Prevention of Chronic Diseases. Report of a Joint WHO/FAO Expert Consultation. 